\title{
Böbrek Hastalıkları ve Protein Metabolizması
}

\author{
Kidney Diseases and Protein Metabolism
}

\author{
Hilal Yıldıran ${ }^{1}$, Feray Gençer ${ }^{2}$
}

Geliş tarihi/Received: 25.02.2018 • Kabul tarihi/Accepted: 05.11.2018

\section{ÖZET}

Böbrek, protein metabolizmasında aminoasitlerin ve peptidlerin sentezi, yıkımı, filtrasyonu, geri emilimi ve idrar yoluyla atılması gibi yolaklarda önemli rolleri olduğu bilinen organdır. Fenilalanin-tirozin dönüşümü, arjinin metabolizması ve transmetilasyon gibi birçok işlevi ile aminoasit metabolizmasına katkı sağlayan böbrekler aynı zamanda düşük molekül ağırlıklı plazma proteinleri ve peptidlerin katabolizması için önemli işleve sahiptir. Böbrek hastalıklarında böbreğin işlev bozuklukları ve/veya kayıplarına bağlı olarak gelişen metabolik asidoz, inflamatuvar süreç, hastalığın tıbbi beslenme tedavisindeki protein kısıtlamaları, diyaliz tedavisi gibi birçok etmen protein metabolizmasında değişikliklere yol açmaktadır. Değişen protein metabolizmasıyla birlikte böbrek hastalığı tanısı almış bireyin diyette aldığı protein miktarı ve türü ön plana çıkmaktadır. Diyaliz almayan böbrek yetmezliği hastalarında gerekli olan durumlarda çok düşük proteinli diyetler yerini ılımlı protein kısıtlamasına bırakırken, diyaliz alan hastalarda artan aminoasit kayıpları ve katabolizma nedeniyle diyetteki protein miktarının arttırılması uygun görülmektedir. Bu derlemede böbreklerin protein metabolizmasındaki rolüne ve böbrek hastalıkları sonucu ortaya çıkabilecek metabolik ve nütrisyonel sorunlara odaklanmak amaçlanmıştır.

\section{Anahtar kelimeler: Böbrek hastalıklarl, protein metabolizması, aminoasit, beslenme}

\begin{abstract}
The kidneys are known to have important roles in pathways such as the synthesis, degradation, filtration, reabsorption and excretion of the amino acids and peptides in protein metabolism. Kidneys that contribute to the metabolism of amino acids with many functions such as phenylalanine-tyrosine transformation, arginine metabolism and transmethylation also have important functions for catabolism of low molecular weight plasma proteins and peptides. Many factors such as metabolic acidosis, inflammatory process, protein restriction in the medical nutrition treatment of the disease and dialysis treatment are caused by changes in protein metabolism in kidney diseases. Along with changing protein metabolism, the amount and type of protein taken by the individual diagnosed with kidney disease come to the fore. While very low protein diets are replaced by moderate protein restriction when necessary in patients with non-dialysis renal failure, in patients receiving dialysis, it is appropriate to increase the amount of protein in the diet due to increased amino acid losses and catabolism. The aim of this review is to focus on the role of the kidneys in protein metabolism and the metabolic and nutritional problems that may arise as a result of kidney diseases.
\end{abstract}

Keywords: Kidney diseases, protein metabolism, amino acids, nutrition

1. İletişim/Correspondence: Gazi Üniversitesi, Sağlık Bilimleri Fakültesi, Beslenme ve Diyetetik Bölümü, Ankara, Türkiye • E-posta: ciftcihilal@hotmail.com (ㄱ) https://orcid.org/0000-0001-7956-5087
2. Gazi Üniversitesi, Sağlık Bilimleri Fakültesi, Beslenme ve Diyetetik Bölümü, Ankara, Türkiye (i) https://orcid.org/0000-0001-5754-7208 


\section{GİRIŞ}

Böbreklerin vücut metabolizmasında atıkların ve ilaçların uzaklaştırılmasında, sıvı dengesinin sağlanmasında, hormonların salınımında, kan basincinın düzenlenmesinde, $\mathrm{D}$ vitamininin aktifleştirilmesinde kırmızı kan hücrelerin üretiminin kontrolünde ve daha birçok olayda önemli rolleri bulunmaktadır (1-4). Böbrek, önemli işlevlerinden birini de aminoasit ve protein metabolizması üzerine göstermektedir. Bozulan böbrek işlevleriyle birlikte bireyde aminoasit ve protein metabolizmasinda aksaklıklar ortaya çıkmaktadır. Her geçen gün metabolizmada yeni etkileri kanıtlanması nedeniyle, sağlıklı böbreklerde gerçekleşen mekanizma ve böbrek hastalarında metabolizmada meydana gelen değişiklerin irdelenmesi tedavide daha etkili yaklaşımlar sağlanmasına katkıda bulunmaktadır (5-7). Bu derleme makalede böbreklerin protein metabolizmasındaki rolüne ve böbrek hastalıkları sonucu ortaya çıkabilecek metabolik ve nütrisyonel sorunlara odaklanmak amaçlanmıştır.

\section{Protein Metabolizmasında Böbreğin Rolü}

Böbrekler aminoasit metabolizmasında önemli bir rol oynamaktadır. $\mathrm{Bu}$ rolünü aminoasitlerin ve peptidlerin sentezi, ylkımı, filtrasyonu, yeniden emilmesi ve idrar yoluyla atılması gibi yolaklarda görev yaparak ortaya koymaktadır. Böbrek, glutamin ve prolinin yıkımı, diğer dokularda kullanılmak üzere serin, tirozin ve arjinin gibi bazı aminoasitlerin sentezinde temel organ olarak görev yapmaktadır. Ayrıca böbrekler, glutatyon yıkımından türeyen bir peptid olan sistein-glisin ve S-adenosilhomosisteinin vücuttan uzaklaştırılmasını sağlamaktadır. Böbrekler aynı zamanda sistemik dolaşıma daha az miktarlarda treonin, lizin ve lösin salınımından sorumludur (6).

Fenilalanin vücutta sentezlenemeyen elzem bir aminoasit olarak bilinmektedir. Ancak tirozin, fenilalaninin, fenilalanin hidroksilaz enzimi tarafindan hidroksilasyonu ile sentezlenebilmektedir. Bu enzim başlıca karaciğer, pankreas ve böbreklerde bulunmaktadır. $\mathrm{Bu}$ nedenle böbrekler tirozin metabolizmasında da büyük önem taşımaktadır. Böbrek hastalıklarında genellikle fenilalanin hidroksilasyonundaki azalmaya bağlı olarak plazma ve kas dokuda tirozin miktarları azalma gösterebilmektedir. $\mathrm{Bu}$ nedenle bu hastalarda plazma ve kas fenilalanin miktarında hafif artış beklenmektedir (8). Artan aminoasit gereksinmesi ile karakterize olan sepsis veya karaciğer hastalığı gibi durumlarda tirozin üretimi yetersiz olabilmektedir. Tirozin eksikliği protein kaybına ve dopamin, norepinefrin veya epinefrin gibi modülatörlerin sentezinde bozulmaya yol açabilmektedir (7).

Böbrekler arjinin metabolizmasinda da rol oynamaktadır. Böbreğe gelen sitrülinden arjinin sentez edilmektedir. Arjinin protein sentezindeki rolüne ek olarak nitrik oksit, kreatin, agmatin ve diğer poliaminlerin öncüsü ve üre döngüsünde bir ara ürün olarak görev yapmaktadır. Vücuttaki arjinin sentezi, özellikle endotoksemi gibi yaşamı tehdit eden koşullarda büyük önem taşımaktadır. Böbrek hastalıklarında arjinin sentezindeki azalmaya ek olarak anoreksiyaya bağlı besinsel arjinin kaynaklarının da tüketilmemesi arjinin havuzunda azalmaya neden olmaktadır (9). Arjininden sentezlenen nitrik oksit kardiyovasküler, nörolojik, immünolojik ve diğer pek çok sistemde farklı rolleri olan biyolojik bir düzenleyici olarak görev yapmaktadır. Ayrıca, nitrik oksit, insülin ve insülin benzeri büyüme faktörü-1 (IGF-1) dahil olmak üzere çeşitli hormonlariçin bir aracı olmakla birlikte, azalmış nitrik oksit düzeyleri bu hormon düzeylerinde düşüşle ilişkilendirilmektedir. Böbrek hastalıklarda azalmış arjinin kaynaklı nitrik oksit düzeylerinde azalmaya ek olarak hastalığa bağlı glukozillenmiş ürünlerin birikmesi, nitrik oksitin hedef dokulara ulaşımını ve etkisini azaltmaktadır. Asimetrik dimetilarjinin gibi nitrik oksit sentaz inhibitörlerinin artması böbrek işlev kaybının bir göstergesi olmasının yanında nitrik oksit sentezini azaltmasıyla kardiyovasküler mortalite ve aterosklerozla ilişkili görülmektedir (10). 
Böbrekler sülfür içeren aminoasitlerin metabolizmasinda rol almaktadır. Metiyonin transmetilasyonunun biyolojik etkileri, çeşitli bileşiklerin biyosentezi ve protein ekspresyonunun epigenetik regülasyonuna katkı sağlamaktadır. S-adenosilhomosistein, metiyonin transmetilasyonunun yan ürünü ve dokularda homosisteinin metabolik öncüsü olarak bulunmaktadır. Böbrekler homosisteini doğrudan dolaşımdan uzaklaştıramasa da S-adenozilhomosisteini uzaklaştırma yeteneği göstermektedir. Özetle, sülfürlü aminoasitlerin metabolik regülasyonunda ve dolaylı olarak insanlarda doku metil transfer reaksiyonlarında böbreklerin görevleri bulunmaktadır (11).

\section{Böbrek Hastalıklarında Protein Metabolizmasını Etkileyen Etmenler}

Böbrekler, özellikle düşük moleküler ağırlıklı plazma proteinleri ve peptidlerinin katabolizması için önemli bir bölge olarak görev yapmaktadır. Glomerulus, sadece düşük moleküler ağırlıklı proteinlerin süzülmesini sağladığından, plazma proteinlerinin böbrek tarafından katabolizması, glomerüler filtrasyon ve ardından tübüler geri emilim ile ortaya çıkmaktadır (12). Yetişkinlik dönemi boyunca böbrek içindeki protein sentezi ve degradasyonunun kontrollü bir şekilde devam etmesi nedeniyle böbrek büyüklüğü ve protein içeriği sabit miktarlarda tutulmaktadır. Ancak, fizyolojik veya patolojik uyaranlara yanıt olarak böbrekte hipertrofi ortaya çıkabilmektedir. Protein sentezi için substrat olan aminoasitler, arteriyel kan akışı veya tübüler bölgeler gibi çeşitli yollarla böbreğe ulaşmaktadır. Ayrıca, glomerulus tarafından geri emilimi gerçekleştirilen düşük molekül ağırlıklı proteinlerin degredasyonu ile ek aminoasit kaynakları oluşmaktadır (13). Böbreklere ulaşan yüksek aminoasit ve protein kaynağı göz önüne alındığında, böbrek hücrelerinin belirli uyaranlar altında hipertrofi geliştirmeye eğilimli olmaları beklenmektedir. Yağ ve karbonhidratlardan ziyade protein alımının böbrek hemodinamiğini önemli ölçüde etkilediği bilinmektedir. Protein alımı ya da aminoasit intravenöz infüzyonları, böbreğe kan akışını ve glomerüler filtrasyon hızını akut olarak arttırmaktadır (14). Böbrek otoregülasyon kaybı ile birlikte erken glomerüler/ tübüler hipertrofi, hiperfiltrasyon ve azalmış nefron kütle kaybının, glomerüloskleroz ve interstisyel fibrozisin gelişimine önemli ölçüde katkıda bulunduğu kabul edilmektedir. Bu koşullar geri dönüşümsüz morfolojik değişiklikler ile karakterize olmakla birlikte, son dönem böbrek yetmezliği tablosu ile ilişkilendirilmektedir $(13,14)$.

Amonyagenez, böbrek protein döngüsü ile bağlantılıdır. Renal sentez ve amonyak atılımı, asitlerin vücuttan etkin bir şekilde uzaklaştırılması için önem taşımaktadır. Buna karşılık, hücre içi amonyak düzeyleri, böbrek tübül hücrelerinde protein dönüşümü için kritik öneme sahiptir. Renal amonyak sentezi, hipertrofi ile ilişkili çeşitli klinik durumlarda artmaktadır. Aynı zamanda, tübül epitelyal hücrelerinde, asidozdan ziyade amonyak üretimindeki artış, tübüler hipertrofi nedeni kabul edilmektedir $(15,16)$.

Böbrek hastalarında, hastalık, tedavi veya eşlik eden hastalıklar ile ilişkili etmenler protein katabolizmasina neden olabilmektedir. Bu etmenler, farklı protein yolakları ve farklı protein havuzları üzerinde etki etmektedir. Protein metabolizmasında meydana gelen değişiklikler ile birlikte yetersiz beslenmenin malnütrisyon ve protein enerji kaybında önemli bir rol oynadığı düşünülmektedir. Bununla birlikte, üremi ve tedavisi de protein metabolizmasını bozabilmektedir. Bu hastalarda vücut proteinlerinin ve kas proteinlerinin azalmasinda etken nedenler metabolik asidoz, protein sentez inhibitörlerinde artış, anabolik etmenlere karşı oluşan direnç, inflamasyon, düşük proteinli diyetler şeklinde sıralanabilmektedir (6).

Metabolik asidoz durumunda kas protein katabolizmasında artışlar görülürken, protein sentezinde azalma ve böbrek işlevinde kötüleşme durumlarıyla karşılaşılacağı bilinmektedir. Metabolik asidozda, böbrekler kandan daha fazla miktarda glutamin ve glisin alırken, bazı amonyak öncülü 
aminoasitleri sistemik dolaşımı geri vermektedir. Üretilen amonyak böbrek protein yıkımı üzerinde fizyolojik ve inhibitör bir etki oluşturmaktadır $(17,18)$. Kronik metabolik asidoz, artmış protein yıkımı ve büyüme geriliği ile ilişkilendirilmekle birlikte yağsız vücut kütle kaybının önemli bir nedeni olabilmektedir. Metabolik asidozun düzeltilmesi hem azot hem de potasyum dengesini arttırmaktadır (19).

Anabolik hormonlara direnç, hiperparatiroidizm, hiperglukagonemi ve tiroid hormon değişikliği gibi çeşitli hormonal bozukluklar hastalarda yağsız vücut kütlesinin kaybına neden olmaktadır. İnsülinde oluşan post reseptör sonrası defektin, hastalarda ortaya çıkan glukoz metabolizmasına bağlı olarak insülin direncinin nedeni olduğu düşünülmektedir. İnsülin direncinin üremik hastalarda kas kaybına neden olabileceği tartışılmaktadır (20,21). Böbrek hasarı kronikleştiğinde büyüme hormonu ve bu hormona aracılık eden IGF-1'e karşı direnç oluşabildiği gösterilmektedir. $\mathrm{Bu}$ durum özellikle üremik çocuklarda azalmış büyümenin yanı sıra, düşük insülin mevcudiyeti, yüksek stres ve açlık hormonları gibi düzenleyici hormonlar ile karakterize edilen koşullar yağsız vücut kütlesinin korunma yeteneğinin azalmasını da beraberinde getirmektedir (19,22).

Böbrek hastalarında, özellikle diyaliz alan hastaların önemli bir yüzdesinde, sistemik bir inflamatuvar yanıtın olduğunu düşündüren proinflamatuvar sitokin düzeyleri artış göstermektedir (19). Dolaşımdaki monositlerin yanı sıra, somatik hücreler proinflamatuvar ve proapoptotik sitokinler üretebilir ve besinsel etmenler hem kas hücreleri hem de adipositler tarafindan sitokin üretimini etkileyebilmektedir. Bu durum protein enerji kaybı ve inflamasyon arasındaki ilişkiyi ortaya koymaktadır (23). Protein yapım ve yıkımının hızlanması akut enfeksiyonun bilinen etkisi olmakla birlikte, protein döngüsünün subakut ve kronik inflamasyon durumuna cevabı net olmamaktadır. Ancak subakut veya kronik enfeksiyonun, oksidasyon ve nitrojen kaybını sınırlamayı sağlayan yanıtının diğer stres durumlarından ayırt edilebileceği ileri sürülmüştür (24).
Diyaliz protein metabolizmasında etkili bir diğer etmen olmakla birlikte, diyalizin beslenme ve protein metabolizması üzerine etkisi değişkenlik göstermektedir. Diyaliz tedavisi, diyet alımını ve beslenme durumunu etkileyen önemli bir etmen olmasının yanında diyaliz ile ilişkili etmenler nedeniyle protein gereksinmelerinin de artmasina neden olmaktadır. Hemodiyaliz tedavisinde özellikle substrat kayıpları ve diyalizin neden olduğu protein katabolizmasının protein metabolizmasını etkilediği düşünülmektedir (19). Periton diyalizinde ise önemli düzeyde glukoz emilimine rağmen, yağ depolarında koruma veya artış ile yağsız vücut kütlesinin kaybı, daha yaygın görülebilmektedir. Periton diyalizinde, açlık durumunda, tek başına dekstroz içeren diyalizat verilmesisonucuortayaçıkanılımlıhiperinsülineminin antiproteolitik etkiye neden olduğu gösterilmektedir. Dekstroz ve aminoasitleri birlikte içeren diyalizat kullanımı, insülin tarafından indüklenen kas proteini yıkımının bastırılması ve aminoasit ile uyarılan kas proteini sentezinin uyarılması nedeniyle çift yönlü olumlu etki ile sonuçlanmaktadır. Bu nedenle, periton diyalizi ile tedavi edilen hastalarda, açlık durumunda veya besin alımı azaldığında, kas kütlesinin dekstroz ve aminoasitlerin birlikte kullanımı ile daha iyi korunması mümkün olmaktadır (25).

\section{Böbrek Hastalıklarında Diyet Proteininin Önemi}

Böbrek hastalıklarında progresyonu belirleyen birçok etmen olmakla birlikte diyetle alınan proteinin miktarı ön plana çıkmaktadır. Özellikle kronik böbrek yetmezliğinde böbrek hastalığının ilerleme hızını azalttığı ve üremik semptomları geciktirdiği düşüncesiyle, düşük proteinli diyetler yıllar öncesinde kullanılmaya başlanmıştır. Bununla birlikte çok düşük proteinli diyetlerle $(\leq 0.3 \mathrm{~g} / \mathrm{kg} / \mathrm{gün})$ birlikte ketoasit analoglarının kullanılması böbrek yetmezliğinde bir başka yaklaşım olarak uygulanmıştır. Bu diyetler hem uygulamasının zor olması hem de malnütrisyona yol açmaları nedeni ile ilerleyen yıllarda sorgulanmaya başlanmıştır. Ancak olumlu ve olumsuz etkileri halen araştırılmaktadır (26,27). Üremi semptomlarının azaltılması ve hastalığın ilerleyişinin yavaşlatılması 
düşük proteinli diyet uygulamasının temel amacı olsa da düşük fosfor içeriği, lipit metabolizması üzerine etki, serbest radikallerin hasarını azaltma ve prostaglandin sentezini azaltma düşük proteinli diyetlerin olumlu etkileri olarak yansıtılmıştır. Aynı zamanda düşük proteinli diyetin preglomerüler vazokonstraksiyon yolu ile antiproteinürik etki sağladığı bildirilmiştir (28). Özellikle 1970’lerden itibaren diyaliz olanaklarının artması ile birlikte, düşük proteinli diyetlerin popülaritesi azalmıştır. Diğer böbrek hastalıklarında uygun diyet proteini hastalığa ve evrelere göre çeşitlilik göstermektedir. Düşük proteinli diyetlerin diyabetik nefropatili hastalarda yüksek, kronik glomerülonefritli hastalarda orta düzey olumlu etkileri görülürken, polikistik böbrek hastalığl, interstitial nefriti ve hipertansif nefrosklerozu olan hastalarda olumlu etkisi görülmemiştir (29).

Amerika Birleşik Devletleri'nde Ulusal Böbrek Vakfı'nın Böbrek Hastalığı Sonuçları Kalite Girişimine (NKF/KDOQI) göre diyaliz tedavisi almayan kronik böbrek yetmezliği hastalarında güncel protein alım önerileri yetişkin bireyler için 0.6-0.8 g/kg/gün'dür. Sağlıklı bireylerde önerilen protein miktarının $0.8 \mathrm{~g} / \mathrm{kg} / \mathrm{gün}$ olduğu düşünülürse, düşük proteinli diyet terminolojisi yanıltıcı olmamalıdır. Diyaliz tedavisi alan hastalarda ise önerilen günlük protein alımı hemodiyaliz için $1.2 \mathrm{~g} / \mathrm{kg}$, periton diyalizi için 1.2-1.3 g/kg’dır (30). Farklı protein kaynaklarının kullanılmasına ilişkin net sonuçlar olmasa da negatif azot dengesinin önlenmesi amaciyla diyet proteininin en az \%50'sinin iyi kalite protein içermesi beklenmektedir. $\mathrm{Bu}$ aşamada proteinin enerji amacıyla kullanılmaması için diyet enerjisinin yeterli sağlanması ön plana çıkmaktadır (31). Diyaliz alan veya almayan KBY hastalarına 60 yaş altında $35 \mathrm{kkal} /$ kg/gün, 60 yaş üstünde ise $30 \mathrm{kkal} / \mathrm{kg} / \mathrm{gün}$ enerji alım önerisi bulunmaktadır (30).

\section{SONUÇ VE ÖNERILER}

Böbreklerin aminoasit ve protein metabolizmasında önemli rolleri olduğu açık şekilde görülmektedir.
Böbrek işlevindeki azalmalar ve kayıplar aminoasit metabolizmasını etkileyerek vücut düzeyinde azalmalara ve/veya birikimlere bağlı olumsuz klinik sonuçlar doğurabilmektedir. Diğer taraftan böbrek hastalıkları nedeniyle bozulan protein metabolizması olumsuz nütrisyonel sonuçlara beden olmaktadır. $\mathrm{Bu}$ aşamada hastalarda neden sonuç ilişkisi iyi irdelenmeli hem tubbi hem beslenme tedavisi buna uygun olarak planlanmalıdır. .

Çıkar çatışması - Conflict of interest: Yazarlar çıkar çatışması olmadığın beyan ederler. - The authors declare that they have no conflict of interest.

\section{KAYNAKLAR}

1. Souma T, Suzuki N, Yamamoto M. Renal erythropoietinproducing cells in health and disease. Front Physiol 2015;6:167.

2. Atherton JC. Regulation of fluid and electrolyte balance by the kidney. Anaesth Intensive Care Med 2006:227-33.

3. Kumar R, Tebben PJ, Thompson JR. Vitamin D and the kidney. Arch Biochem Biophys 2012;523:77-86.

4. Wadei HM, Textor SC. The role of the kidney in regulating arterial. Nat Rev Nephrol 2012;8:602-9.

5. Martin WF, Armstrong LE, Rodriguez NR. Dietary protein intake and renal function. Nutr Metab 2005;2:25. doi: 10.1186/1743-7075-2-25.

6. Garibotto G, So A, Saf S, Bonanni A, Mannucci I, Verzola D. Amino acid and protein metabolism in the human kidney and in patients with chronic kidney disease. Clin Nutr 2010;29:424-33.

7. Nair KS. Amino acid and protein metabolism the kidney as a site of in vivo. J Ren Nutr 2005;15:28-33.

8. Kopple JD. Phenylalanine and tyrosine metabolism in chronic kidney failure. J Nutr 2007;137:1586-90.

9. Brosnan ME, Brosnan JT. Renal arginine metabolism. J Nutr 2004;134:2791-5.

10. Popolo A, Adesso S, Pinto A, Autore G, Marzocco S. L Arginine and its metabolites in kidney and cardiovascular disease. Amino Acids 2014;46:2271-86.

11. Brosnan JT, Brosnan ME. The sulfur-containing amino acids: An overview. J Nutr 2006;136:1636-40.

12. Maack T, Johnson V, Kau ST, Figueiredo J, Sigulem D. Renal filtration, transport and metabolism of lowmolecular- weight proteins: A review. Kidney Int 1979;16:251-70.

13. Fine L. The biology of renal hypertrophy. Kidney Int 1986;29:619-34. 
14. Al-awqati Q. Kidney growth and hypertrophy: the role of mTOR and vesicle trafficking. J Clin Invest 2015;125:2267-70.

15. Weiner ID, Verlander JW. Recent advances in renal ammonia metabolism and transport. Curr Opin Nephrol Hypertens 2017;25:436-43.

16. Weiner I, Verlander J. Renal ammonia metabolism and transport. Compr Physiol 2015;3:201-20.

17. Chen W, Abramowitz MK. Metabolic acidosis and the progression of chronic kidney disease. BMC Nephrol 2014;15:1-8.

18. Siener R. Dietary treatment of metabolic acidosis in chronic kidney disease. Nutrients 2018;10:512. doi: 10.3390/nu10040512.

19. İkizler AT. Optimal nutrition in hemodialysis patients. Adv Chronic Kidney Dis 2013;20:181-9.

20. Deger SM, Hewlett JR, Gamboa J, Ellis CD, Hung AM, Siew $\mathrm{ED}$, et al. Insulin resistance is a significant determinant of sarcopenia in advanced kidney disease. Am J Physiol Endocrinol Metab 2018;315:1108-20.

21. Dong J, İkizler AT. New insights into the role of anabolic interventions in dialysis patients with protein energy wasting. Curr Opin Nephrol Hypertens 2009;18:469-75.

22. Mahesh S, Kaskel F. Growth hormone axis in chronic kidney disease. Pediatr Nephrol 2008;23:41-8.

23. Van Hall G. Cytokines: muscle protein and amino acid metabolism. Curr Opin Clin Nutr Metab Care 2012;15:8591.
24. Wilmore DW. Infection and injury: effects on whole body protein metabolism. In:Nesheim R,Vanderveen J ,editors. The Role of Protein Amino Acids Sustaining and Enhancing Performance. Washington: National Academies Press; 1999. p. 155-68.

25. Garibotto G, Sofia A, Saffioti S, Bonanni A, Mannucci I, Parodi EL, et al. Effects of peritoneal dialysis on protein. Nutr Metab Cardiovasc Dis 2013;23:25-30.

26. İkizler TA. Safety of low-protein diets and ketoanalogue supplementation in CKD. Kidney Int Reports 2018;3:5102.

27. Fouque D, Mitch WE. Low-protein diets in chronic kidney disease : are we finally reaching a consensus ? Nephrol Dial Transplant 2015;30:6-8.

28. De Jong P, Anderson S, De Zeeuw D. Glomerular preload and afterload reduction as a tool to lower urinary protein leakage: Will such treatments also help to improve renal function outcome? J Am Soc Nephrol 1993;3:1333-41.

29. Oyan B, Altun B, Usalan C. Kronik böbrek yetmezlï̆ininde proteïn aliminin progresyon üzerïne etkïsï. Türk Nefroloji Diyal ve Transplant Derg 1999;4:167-73.

30. Kopple JD. National Kidney Foundation K/DOQI Clinical Practice Guidelines for Nutrition in Chronic Renal Failure. Am J Kidney Dis 2001;37:66-70.

31. Jee Ko G, Obi Y, Tortoricci AR, Kalantar-Zadeh K. Dietary protein intake and chronic kidney disease. Cur Opin Clin Nutr Metab Care 2017;20:77-85. 